\title{
ZINC IN THE MATURING RAT TESTIS
}

\author{
J. PAŘ́ZZEK*, J. C. BOURSNELL, MARY F. HAY, \\ A. BABICKY $\dagger^{\dagger}$ AND D. M. TAYLOR \\ A.R.C. Unit of Reproductive Physiology and Biochemistry, Cambridge $\ddagger$, and \\ Department of Physics, Institute of Cancer Research, \\ Royal Cancer Hospital, Sutton, Surrey
}

(Received 3rd March 1966)

Summary. Using the method of radio-activation analysis, zinc was determined in the testes of rats varying in age from 7 to 58 days.

During the first month of life the zinc concentration remained fairly constant (120 ng/mg testicular dry weight), and no decrease in testicular zinc concentration occurred at the time when the rat testis first acquires its sensitivity to the necrotic action of cadmium (approximately 9 days of life). This is of special significance in view of the fact that parenterally administered zinc salts counteract the action of cadmium.

During the second month of life, the concentration of testicular zinc increased considerably. This increase, which coincides roughly with the time when spermatids are transformed into spermatozoa, may well be related to the formation of intracellular zinc-metalloproteins, including certain zinc-containing enzymes in spermatozoa.

\section{INTRODUCTION}

Differences in the sensitivity of rat testes to the necrotic action of small amounts of injected cadmium salts at different stages of ontogenetic development (Paŕízek, 1960) suggest that, at a definite stage in the post-natal differentiation of the male gonad, a critical change in the testes occurs as a result of which that organ becomes responsive to the peculiar action of cadmium. The testis can be protected against this action by large amounts of zinc salts injected simultaneously with the cadmium salt (Paŕizek, 1957). Zinc itself is a characteristic constituent of the male reproductive organs and semen, and plays a definite, even if not fully understood, role in reproduction (Mann, 1964). It would thus be of interest to compare the zinc content of the immature testis with that of the adult rat, and to relate the levels of zinc to the phenomenon of cadmium necrosis. In particular, it would be important to explore the possibility that, at the moment when the cadmium begins to act necrotically, the zinc concentration of the testis is changing. Furthermore, by determining the

\footnotetext{
* Present address: Czechoslovak Academy of Sciences, Institute of Physiology, Budějovická 1083, Prague 4.-Krč. Czechoslovakia.

$\dagger$ Present address: Czechoslovak Academy of Sciences, Isotope Laboratory of the Institutes for Biological Research, Prague, Czechoslovakia.

$\ddagger$ Postal address: Animal Research Station, 307 Huntingdon Road, Cambridge.
} 
zinc content of testes at different ages of post-natal development it might be possible to find out whether the stage at which zinc is incorporated into the developing testis is related to any particular phase of spermatogenesis.

Determinations of trace amounts of zinc in such very small organs as the testes of immature rats present two particularly difficult technical problems connected with: (i) the sensitivity of available methods, and (ii) the avoidance of external contamination brought about by the manipulative and chemical procedures. The quantitative determination of zinc, using classical chemical methods, would require a very large number of animals if adequate sensitivity were to be obtained. It was, therefore, decided to use the method of radioactivation analysis as the most sensitive method available for the quantitative determination of the zinc. This method also has the merit that the danger of possible external contamination is limited to the stage of collecting the material. In addition, the possible error due to loss of the micro-element during any analytical procedure can be safely controlled. In brief the radio-activation method involves the irradiation, by thermal neutrons in a graphite-moderated reactor, of the zinc and other elements present in dried samples of tissue. The irradiated material contains a large number of radio-nuclides from which the zinc is separated by: (1) allowing short-lived nuclides to decay, (2) chemical extraction of the radio-zinc (with added non-radio-active carrier) from the tissue after wet incineration, and (3) determination of the specific gamma emission from the radio-zinc by a gamma-ray spectrometer.

\section{MATERIALS AND METHODS}

The rats were bred from a colony kept at the Animal Research Station and maintained on a standard laboratory diet (Oxoid $41 \mathrm{~B}$ ). On the 2nd day after birth the number of young which were kept with any one mother was reduced to eight by the removal of some of the females in the litter.

On days indicated in Text-figs. 1 and 2 the rats, ranging in age from 7 to 58 days, were killed by decapitation. One testis of each male rat was removed for zinc analysis, avoiding contamination with external zinc as described below. The other testis was fixed in Bouin's fluid for histological determination of the stage of differentiation of the seminiferous tubules.

The method used for zinc analysis was adapted from that described by Banks, Tupper, White \& Wormall (1959). Every piece of apparatus associated with this work was rigorously cleaned by immersion overnight in $6 \mathrm{~N}-\mathrm{HCl}$ and then washed at least seven times with water de-ionized by passage through a mixed ion-exchange column (Elga Products Ltd). This water was tested for the absence of zinc with dithizone. The small 5-mm internal diameter snapclosure polythene containers and lids ('pill packs' cut down to a length of $10 \mathrm{~mm}$ ), in which material was placed for irradiation, were treated overnight with aqua regia $\left(3 \mathrm{vol} . \mathrm{HCl} / \mathrm{l}\right.$ vol. $\left.\mathrm{HNO}_{3}\right)$ to remove any zinc stearate or other material which sometimes contaminates these vessels. They were then washed three times with de-ionized water and immersed overnight in $6 \mathrm{~N}-\mathrm{HCl}$ followed by seven rinsings with de-ionized water as above. The cleaned polythene snap closures were dried over $\mathrm{P}_{2} \mathrm{O}_{5}$. 
In order to avoid contamination from metals, forceps were constructed from Perspex and micro scalpels were prepared from suitable pieces of broken glass microscope slides. All these instruments were cleaned before use with $6 \mathrm{~N}-\mathrm{HCl}$ and rinsed as above. Great care was taken in opening the abdominal cavities of the rats to avoid handling or contaminating with metal instruments any tissues near the testes.

Wet and dry weight values were obtained for each sample of testicular material, which in most cases represented testes pooled from several rats of the same age and litter. The excised testes, after dissection on a pre-cleaned sheet of polythene, were placed in pre-weighed polythene boxes numbered according to the sample. These boxes were closed with tightly fitting lids, using polythene gloves, and weighed. In order to dry the contents for irradiation the boxes were re-opened, using the polythene gloves, placed in a desiccator over $\mathrm{P}_{2} \mathrm{O}_{5}$, and dried to constant weight.

The dry contents of these polythene boxes were transferred to the preweighed polythene snap-closure containers. After closing, these containers were again weighed. Identical control containers were prepared which held either no sample of tissue (blanks) or standard amounts of MAR zinc acetate solution (equivalent to 1 or $10 \mu \mathrm{g} \mathrm{Zn}$ ) dissolved in de-ionized water and dried over $\mathrm{P}_{2} \mathrm{O}_{5}$ in situ. Some of the blank controls had previously contained a volume of de-ionized water equal to the volume of the zinc acetate solutions. This water was also removed over $\mathrm{P}_{2} \mathrm{O}_{5}$ in a desiccator as above. No radio-active zinc was found after irradiation of the empty tubes within the limits of sensitivity of the method (0.01 $\mu \mathrm{g} \mathrm{Zn)}$.

Normally, enough polythene snap-closure containers were prepared at any one time to fill a $7 \times 2.5 \mathrm{~cm}$ irradiation can (A.E.R.E. Pattern). To avoid metallic contamination from the cans, the snap-closure containers were assembled and wrapped in a suitable piece of cleaned thin polythene sheet before insertion in the can. Great care was taken in distributing the samples of tissues from different age groups in any one irradiation can in order to minimize errors due to possible inhomogeneity of the reactor neutron flux in the volume of the can. The zinc acetate standards and the blank containers were of sufficient number and distribution for the same reason. The cans were irradiated in the reactor BEPO at Harwell at a mean neutron flux of $10^{12}$ for 7 days.

The high flux and long irradiation time were employed because it was advantageous to use the longer lived ${ }^{65} \mathrm{Zn}$ (245 days half-life) instead of the ${ }^{69 \mathrm{~m}} \mathrm{Zn}$ (14 hr half-life) used by Banks et al. (1959). The prolonged periods of time required for the chemical extraction of $\mathrm{Zn}$ from the irradiated tissues and for the transport of that extracted material to the Institute of Cancer Research for measurement precluded the use of the short half-life nuclide. The use of ${ }^{65} \mathrm{Zn}$ also permitted a sufficient period to elapse for the complete decay of many short lived radio-active contaminants, particularly ${ }^{24} \mathrm{Na}$ and ${ }^{42} \mathrm{~K}$. The potential error was thereby lessened and both the amount of radio-active material and the dose-rate to the individual were greatly reduced (Boursnell, 1958). In addition it was possible to measure with a gamma ray spectrometer the specific gamma radiation from ${ }^{65} \mathrm{Zn}$ alone. Calculations on data obtained 
from Koch (1960) showed that although ${ }^{65} \mathrm{Zn}$ could be produced by the neutron irradiation of ${ }^{65} \mathrm{Cu}$, the amount of the zinc nuclide produced from the expected copper content of the tissues could be totally neglected.

The irradiated material as received from Harwell was allowed to decay for about 7 days before further treatment. The cans were then opened and the contents of the polythene containers tipped into $100 \mathrm{ml}$ Kjeldahl flasks containing concentrated $\mathrm{HNO}_{3}, \mathrm{H}_{2} \mathrm{SO}_{4}$ and $\mathrm{H}_{2} \mathrm{O}_{2}$ and $50 \mu \mathrm{g}$ zinc acetate (as carrier). The polythene containers were repeatedly rinsed out with concentrated $\mathrm{HNO}_{3}$ followed by $6 \mathrm{~N}-\mathrm{HCl}$. The separation of the irradiated samples from their containers was made necessary as the long irradiation of the polythene rendered it sticky and extremely difficult to incinerate, in marked contrast to the behaviour of non-irradiated polythene or of the short term irradiated polythene used by Banks et al. (1959). Nevertheless, tests showed that all the ${ }^{65} \mathrm{Zn}$ had been removed by rinsing with the acids as described. The material in the Kjeldahl flasks was then incinerated.

When the mixture was completely clear $(2$ to $3 \mathrm{hr}$ ) the cooled contents of the Kjeldahl flasks were neutralized with conc. $\mathrm{NH}_{3}$ while cooling in an ice bath. The neutralized material was then transferred to a separating funnel for extraction with dithizone. The exhaustive extraction of the zinc with a solution of dithizone in carbon tetrachloride followed the method of Banks et al. (1959) except that, after the final separation, the solution of zinc (as $\mathrm{ZnCl}_{2}$ ) was added to $1 \mathrm{~g}$ of Amberlite IR-120 (H) resin.

A considerable advantage was obtained by absorbing the ${ }^{65} \mathrm{Zn}$ on the resin as the geometry of the counting system was improved and with it the sensitivity. It also facilitated the transport of the samples to the Institute of Cancer Research where the measurements of the radio-activity were made in a 5 -in. $(12.5 \mathrm{~cm})$ diameter $\times 6$-in. $(15 \mathrm{~cm})$ high well-type thallium activated sodium iodide crystal detector coupled to a 100 channel pulse-height analyser. This enabled the radiochemical purity of the ${ }^{65} \mathrm{Zn}$ to be confirmed before final measurements of its activity were made in the energy band containing the $1.12 \mathrm{MeV}$ photopeak.

\section{RESULTS AND DISGUSSION}

Text-figs. 1(a) and (b) give the total $\mathrm{Zn}$ present in the testes of rats in each group plotted against the total wet weight of the testes in each group.

Text-fig. 2 presents the values for $\mathrm{Zn} / \mathrm{mg}$ dry weight testicular tissue plotted against age of rat.

The results have shown that the selection of the method of radio-activation analysis was the correct one in that it was sensitive enough, and disposed of the need to accumulate a large number of testes from each age group. This enabled us to use, for a single $\mathrm{Zn}$ determination, the testes from only one litter. In this way, also, the biological variation within one sample was lessened.

One very great advantage of the radio-activation method of analysis was that it was possible to add carrier zinc after the irradiation. It was therefore possible to follow the stages of the chemical purification with dithizone, making sure that no losses occurred on the way. Thus we could be certain that all the ${ }^{65} \mathrm{Zn}$ present in the irradiated sample was measured. 
In addition, the measurement of the gamma spectrum of the purified material ensured that the only element measured was zinc, without interference from any other radio-active contaminant.

It was felt that these great advantages more than out-weighed the laboriousness of the method and the consequent limit in the number of analyses which was possible in a given time.

From the results it is possible to draw four main conclusions. Firstly, when the testes begin to be sensitive to cadmium action, that is at the age of approximately 9 days (Parrizek, 1960), their zinc content per unit weight is not decreasing. Yet, an injection of zinc as mentioned earlier protects the testis from the

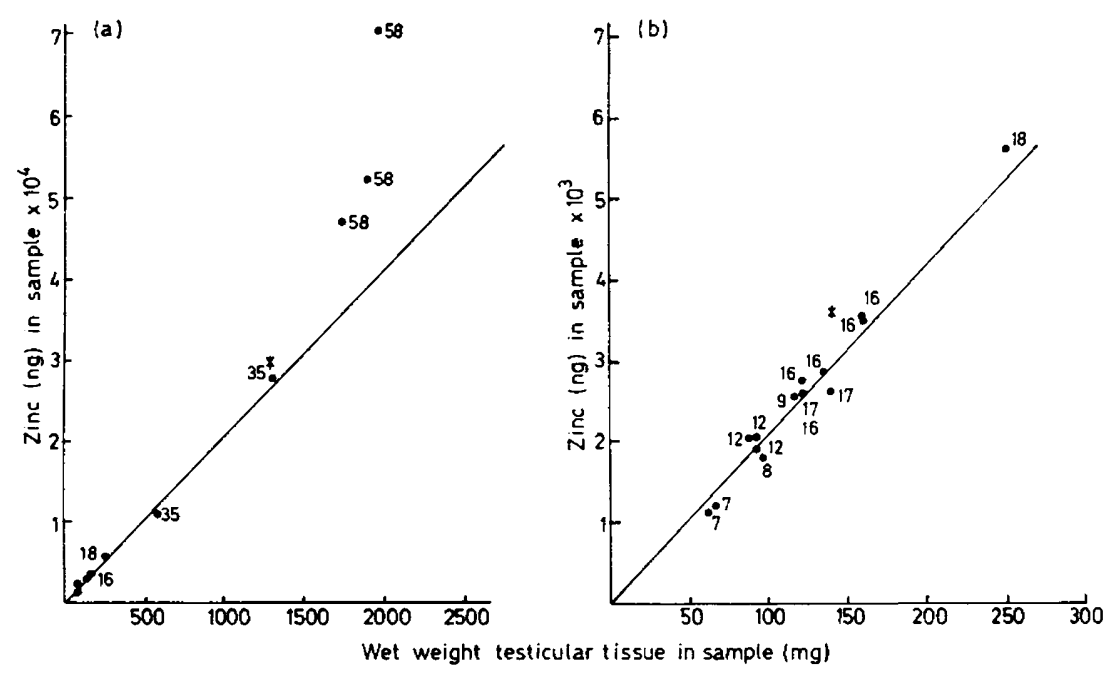

TEXT-FIG. 1. Zinc [ng $\left.\left(10^{-3} \mu \mathrm{g}\right)\right]$ present in the testes of rats in each group plotted against the total wet weight of the testes in each group. (a) Samples from rats of all ages. (b) Samples from rats aged 7 to 18 days only. Ordinates and abscissae ten times scale in Text-fig. 1(a). Gradient of lines identical in both graphs. Figures against points indicate the age of rat in days.

Numbers of testes (from same litter) in samples as follows: 7 and 8 days, $4 ; 9$ days, $3 ; 12$ days, $2 ; 16$ days, 2 or $3^{*} ; 17$ and 18 days, $2 ; 35$ days, 1 or $2^{*} ; 58$ days, 1 . (Asterisks indicate sample containing extra testis.)

necrotic action of cadmium (Paŕzek, 1957). Thus it would seem that the sudden development of sensitivity to cadmium cannot be due to a falling zinc concentration in the gonad. On the contrary, it would appear that there is actually a small but statistically significant increase in the zinc concentration towards the end of the first 10 days of life, that is at the time when sensitivity to cadmium develops. This increase in zinc may perhaps be related to some morphological change which occurs at that stage of testicular development, such as the appearance of the first spermatocytes.

The histological examination of the testes (Plate 1) showed that primary spermatocytes first appeared at 9 days. Few, if any, spermatocytes were present at 8 days, and definitely none at 7 days. At 9 and 12 days the primary spermatocytes were in the leptotene stage. No obvious changes were observed in the 
supporting cells up to 16 days, an observation in agreement with those of Clermont \& Perey (1957) and Sapsford (1962).

Secondly, the zinc content per unit weight of the testis is sensibly constant during the pre-pubertal period (about 120 nanograms $\mathrm{Zn} / \mathrm{mg}$ testicular dry weight), although the size of the testes increases nearly 40 times during this period (10 to 35 days).

Thirdly, the results (comparing Text-figs. 1 and 2) indicate that there is a closer correlation between total $\mathrm{Zn}$ and fresh weight of testis than there is between zinc/unit dry weight of testis and age of rat.

Fourthly, there is a considerable increase (rising to about $200 \mathrm{ng} / \mathrm{mg}$ testicular dry weight at 58 days) in the zinc content/unit dry weight during the 2 nd

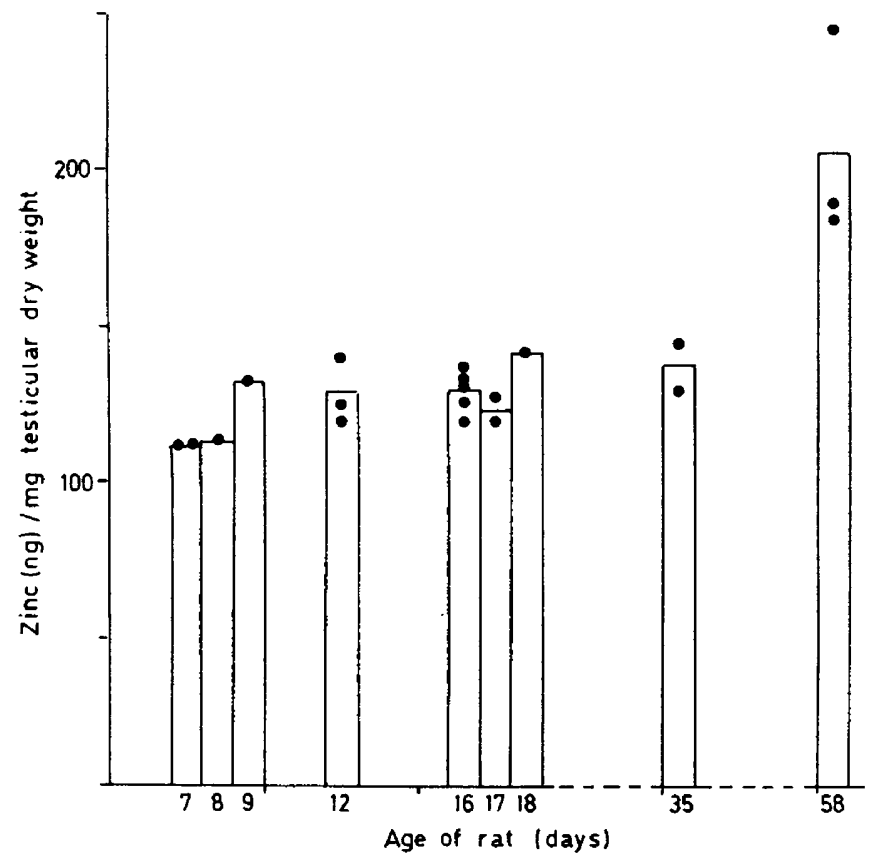

TEXT-FIG. 2. Zinc $\left[\mathrm{ng}\left(10^{-3} \mu \mathrm{g}\right)\right] / \mathrm{mg}$ dry weight testes, as a function of the age of the rat.

month of post-natal life. This may well be related to the fact that, at this time, spermatids are being transformed into spermatozoa (Plate 1), the latter being well known to contain a large amount of protein-bound zinc. It seems probable that while the spermatids are ripening zinc-metalloproteins are synthesized on an increasing scale in the testes. This would explain the increase in the zinc content per unit weight of testicular tissue. At least part of this increase could be attributed to the increased activity of such zinc-containing enzymes as, for example, lactate dehydrogenase in the mitochondrial sheath of the sperm cells (Lojda \& Pařízek, 1963).

Some preliminary experiments were carried out (with the kind co-operation of Dr Bennett) using the agar gel electrophoretic method of Bennett \& Boursnell (1962) and Bennett (1962) in order to identify the testicular proteins which 


\section{PLATE 1}

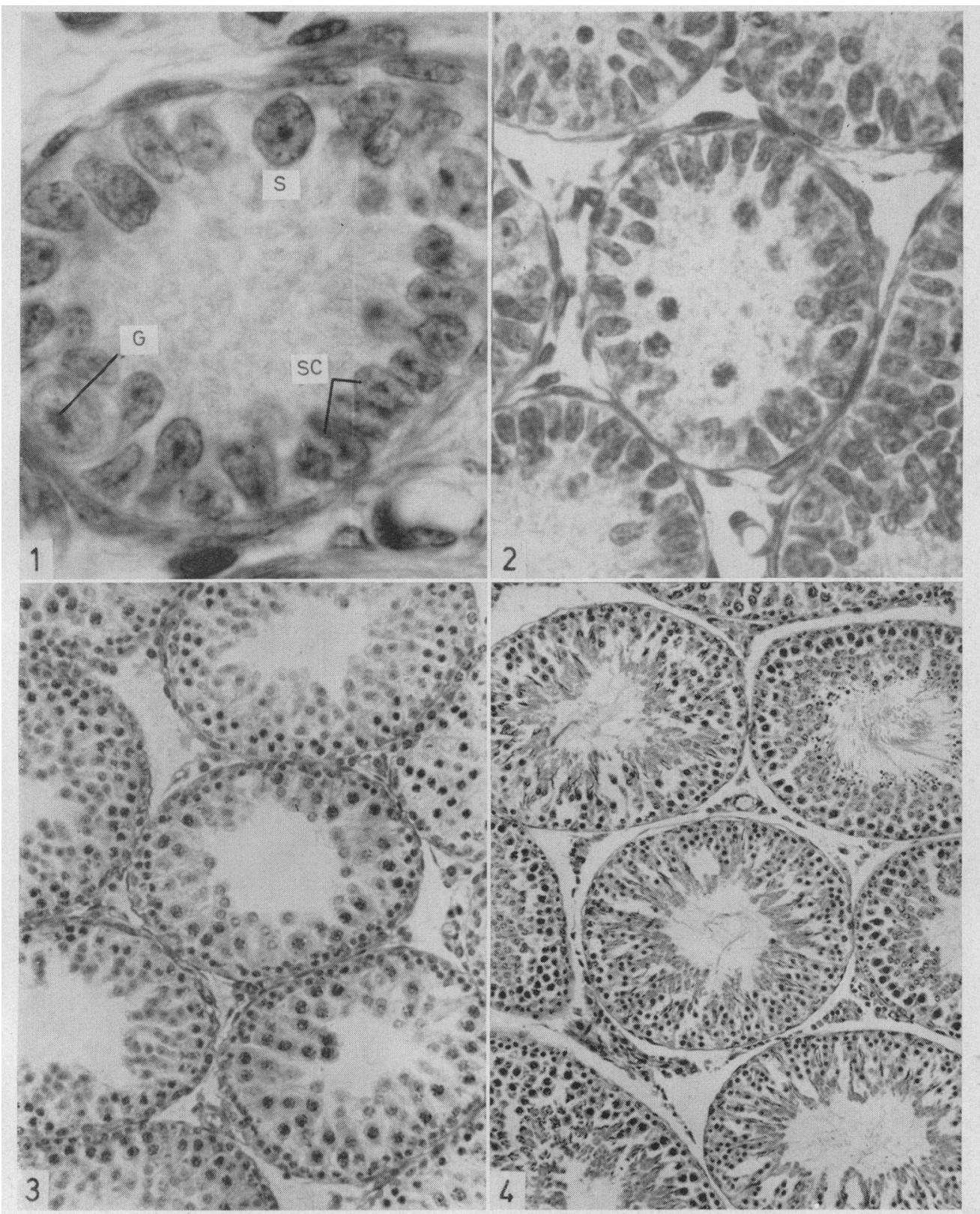

Transverse sections of seminiferous tubules from rats of different ages. Testes fixed in Bouin's fluid. Sections shown in Figs. 1, 3 and 4 stained with Ehrlich's haematoxylin and chromotrope 2R. Section shown in Fig. 2 stained with Heidenhain's iron haematoxylin.

lic: 1. Seminiferous tubule of 7-day rat showing gonocytc (G), spermatogonium (S) and supporting cells (SC). $\times 1300$.

likr. 2. Seminiferous tubule of 12-day rat showing primary spermatocytes in leptotene. $\times 660$.

I'It: 3. Scminiferous tubules of 35-day rat showing primary spermatocytes and spermatids. $\times 210$.

lis. 4. Seminiferous tubules of rat aged 2 months showing spermatozoa. $\times 130$.

(Facing p. 506) 
might be responsible for the increase in the zinc content during the 2nd month. Using zincone, it has been possible to show the presence of protein bound zinc in several of the electrophoretically separated fractions. It is hoped to continue this line of investigation in the future.

\section{ACKNOWLEDGMENTS}

This work was carried out during the tenure of a Population Council Fellowship by one of us (J.P.) and the kind support of this work by the Population Council is gratefully acknowledged. We would like to take this opportunity also to thank Dr T. Mann for helpful discussion and for providing facilities at the Animal Research Station.

During this work, another author (A.B.) was in receipt of an I.A.E.A. Fellowship which enabled him to work at the Royal Cancer Hospital, Sutton, Surrey and the kind support of both these organizations is gratefully acknowledged.

We would like to thank Miss G. E. Skeats and Dr G. R. W. Oliver of the Radiochemical Gentre Production Unit, Harwell, for their help in irradiation, and Dr R. Tupper of the Medical College of St Bartholomew's Hospital, London, for his valuable advice in the early stages of this work.

We would like to acknowledge the great help of Mr Laffling and his staff for providing the rats and keeping the litters during the course of this work. The technical assistance of Miss Denese Cole is also gratefully acknowledged.

\section{REFERENCES}

Banks, T. E., Tupper, R., White, E. M. A. \& Wormall, A. (1959) Micro-determination of zinc in blood and other tissues by neutron activation analysis. Int. F. appl. Radiat. Isotopes, 4, 221.

BenNetr, J. P. (1962) A continuous-scanning attachment for the electrophotometric measurement of proteins after agar gel electrophoresis. Biochim. biophys. Acta, 63, 398.

BenNETt, J. P. \& BoursnelL, J. C. (1962) Improvements in the method for the electrophoretic separation of proteins on agar gel. Biochim. biophys. Acta, 63, 382.

Boursneld, J. G. (1958) Safety techniques for radioactive tracers. Cambridge University Press.

Clermont, Y. \& Perey, B. (1957) Quantitative study of the cell population of the seminiferous tubules in immature rats. Am. F. Anat. 100, 241.

Косн, R. C. (1960) Activation analysis handbook. Academic Press, New York.

LojDA, Z. \& PAŔízek, J. (1963) Ontogenic development and topo-chemistry of testicular dehydrogenases with special reference to zinc and to cadmium necrosis of the testes. Physiologia bohemoslov. $12,512$.

MANN, T. (1964) The biochemistry of semen and of the male reproductive tract. Methuen, London.

PAŘizek, J. (1957) The destructive effect of cadmium ion on testicular tissue and its prevention by zinc. J. Endocr. 15, 56.

PaŘízeK, J. (1960) Sterilization of the male by cadmium salts. 7. Reprod. Fert. 1, 294.

SAPsFord, C. S. (1962) Changes in the cells of the sex cords and seminiferous tubules during the development of the testis of the rat and mouse. Aust. F. Zool. 10, 178. 